\title{
Epizootic amebiasis outbreak in wild black howler monkeys (Alouatta caraya) in a wildlife facility during captivity prior to translocation - Recommendations to wildlife management programs
}

\author{
Surto epizoótico de amebíase em Bugio preto (Alouatta caraya) provenientes de vida livre \\ durante o cativeiro prévio a translocação - Recomendações a programas de manejo de fauna
}

\author{
Alexander GENOY-PUERTO ${ }^{1,2}$; Renata Carolina Fernandes SANTOS ${ }^{1,3}$; Thaís GUIMARÃES-LUIZ ${ }^{4}$; \\ Angélica María SÁNCHEZ-SARMIENTO ${ }^{1}$; Rogério Loesch ZACARIOTTI'; José Luiz CATÃO-DIAS ${ }^{1}$; Eliana \\ Reiko MATUSHIMA ${ }^{1}$
}

\footnotetext{
${ }^{1}$ Universidade de São Paulo, Faculdade de Medicina Veterinária e Zootecnia, Departamento de Patologia, Laboratório de Patologia Comparada de Animais Selvagens, São Paulo - SP, Brazil

${ }^{2}$ Universidad de Las Américas, Facultad de Ciencias de la Salud, Escuela de Medicina Veterinaria y Zootecnia - Quito, Ecuador ${ }^{3}$ Instituto Brasileiro para Medicina da Conservação - TRÍADE, Recife - PE, Brazil

${ }^{4}$ Secretaria do Meio Ambiente do Estado de São Paulo, Coordenadoria de Biodiversidade e Recursos Naturais, Centro de Fauna Silvestre, São Paulo - SP, Brazil

${ }^{5}$ Universidade Cruzeiro do Sul, Laboratório de Reprodução Animal, São Paulo - SP, Brazil
}

\begin{abstract}
The capture and quarantine of non-human primates could be necessary in some circumstances including those required under environmental permit. Mortality is undesirable for wildlife management programs and could be related to opportunistic pathogens, for example, deaths due to intestinal protozoa infection outbreaks as described here. Parasitological, necroscopic, microbiological, and molecular tests were used in the diagnosis of severe necrotic enteritis leading to death of three female and two male black howler monkeys (Alouatta caraya) captured and held in quarantine prior to translocation. Parasitological tests showed the presence of cysts of Entamoeba histolytica/dispar (5/5), Entamoeba coli (5/5) and Giardia duodenalis (1/5). Necroscopic assessment revealed areas of severe multifocal necrosis in the intestinal mucosa and submucosa. Histopathological examination revealed the presence of structures morphologically compatible to Entamoeba spp. in all individuals examined. Furthermore, $G$. duodenalis $(1 / 5)$ was demonstrated by the nested PCR technique. During temporary captivity of non-human primates in management programs, proper handling protocols, including fast or immediate destination, are suggested in order to mitigate the negative effects of stress and decrease the risk of infections.
\end{abstract}

Keywords: Neotropical primate. Entamoeba spp.. Necrotic enteritis. Giardia spp..

\section{Resumo}

Óbitos por infecções causadas por protozoários intestinais são indesejáveis para programas de manejo de fauna, exigidos no âmbito do licenciamento ambiental e que demandam a captura e quarentena de primatas não humanos. Exames coproparasitológicos, necroscópicos, microbiológicos e moleculares foram utilizados para a confirmação do diagnóstico de uma severa enterite necrótica que levou a óbito três fêmeas e dois machos de Alouatta (A.) caraya capturados e mantidos em quarentena prévia à translocação. Exames coproparasitológicos revelaram a presença de cistos de Entamoeba (E.) histolytica/dispar (5/5), Entamoeba (E.) coli (5/5) e Giardia (G.) duodenalis (1/5). A avaliação necroscópica revelou áreas de necrose multifocal severa na mucosa e submucosa intestinal. A análise microscópica revelou a presença de estruturas morfologicamente compatíveis com trofozoítos do gênero Entamoeba spp. em todos os indivíduos examinados. Além disso, G. duodenalis (1/5) foi demonstrada pela técnica de Nested PCR. Sugere-se que quando for necessário o cativeiro temporário de primatas, deverão ser adotados protocolos de manejo adequados buscando a destinação imediata dos animais, de moto a mitigar os efeitos negativos do estresse e reduzir o risco da ocorrência de infecções.

Palavras-chave: Primatas neotropicais. Entamoeba spp.. Enterite necrótica. Giardia spp.. 
Correspondence to:

Alexander Genoy-Puerto

Avenida de los Granados E12-41 y Colimes

EC170125, Quito, Pichincha, Ecuador

e-mail: alexander.genoy@udla.edu.ec

Received: 11/12/2015

Approved: 01/06/2016

\section{Introduction}

Black howler monkey (A. caraya) is a neotropical non-human primate with the broadest geographical distribution in Brazil. It is at risk of extinction in São Paulo due to devastation or fragmentation of its habitat, since there is currently only $1 \%$ of the original vegetation of this area (KIERULFF; CARVALHO, 2009). This occurred during the construction of hydroelectric plants. Management and wildlife conservation programs have been developed in order to mitigate these factors in wildlife. These programs conduct the prior monitoring of populations and subsequent capture and quarantine of monkeys, so that they are finally sent to scientific institutions and/or zoos or translocated to other similar areas near those directly affected by the construction.

Intestinal protozoa are a common finding in neotropical monkeys and the most frequent species of parasites detected, being usually opportunistic and non-pathogenic. However, these agents can lead individuals in immune-suppression situations to death (AMATO et al., 2002; CRISTÓBALAZKARATE et al., 2010; MONTENEGRO et al., 2010). Immune-suppression occurs during periods of chronic stress, which may be due to factors such as environmental disturbance, inadequate maintenance in captivity, transportation, release, adaptation to a new group, among others (MOBERG, 2000; TEIXEIRA et al., 2007). Influence of such factors in stress in $A$. caraya have been documented during wildlife management programs (SÁNCHEZSARMIENTO et al., 2015).

Entamoeba spp. and Giardia spp. may be considered the main species of protozoa with zoonotic potential with high clinical significance
(THOMPSON; SMITH, 2011). Giardia spp. presents seven different genotypes, among them $\mathrm{A}$ and $\mathrm{B}$, which are known to infect humans, non-human primates and a wide variety of mammals (VOLOTÃO et al., 2008). Its life cycle has two stages; cysts are responsible for fecal-oral transmission and trophozoites are responsible for the onset of infection in the duodenum of the host (THOMPSON, 1994). In the life cycle of Entamoeba, the cyst (also its transmission state) occasionally germinates in the duodenum and originates trophozoites that will settle in the colon and cecum (SCHUSTER; VISVESVARA, 2004).

The management of populations of non-human primates implies a zoonotic hazard, since there is a risk of transmitting protozoan agents to humans. It must also be considered that monkeys have a greater risk of obtaining bacterial and viral infections from humans. In this context, increased personal protection and a thorough etiological approach are suggested (ULRICH et al., 2010). In addition, research on parasitic infections in animals from wildlife and those kept in captivity provides new tools for disease prevention and optimization of wildlife management plans as proposed in this study.

\section{Material and Methods}

\section{Captivity}

A small hydropower plant (SHP), built in SapucaíMirim River, state of São Paulo, Brazil $\left(20^{\circ} 28^{\prime}\right.$ S and $47^{\circ} 52^{\prime} \mathrm{W}$ ), has a wildlife screening center (WSC) in order to support rescue and monitoring activities of wildlife directly affected by vegetation suppression and flooding of the area for reservoir construction. Between May and November 2009, 22 A. caraya were captured before vegetation suppression. The quarantine period referred to non-human primates was 60 days prior to translocation. Early in this period, animals were evaluated by physical and biometrical tests and biological samples were collected. All howler monkeys were considered healthy in physical tests; with good body condition, without any lesions and 
evidence of changes on palpation or auscultation. Prophylactically, animals were dewormed with ivermectin (Ivomec $200 \mu \mathrm{g} / \mathrm{kg}$, Merial, Campinas, SP, Brazil). The cages were in the external area of WSC, distant 200 meters from each other. Each cage $(2.50 \mathrm{~m}$ x $2.50 \mathrm{~m} \mathrm{x} 2.50 \mathrm{~m}$ cages) was equipped with a bed, trunks and a platform for food and water, and had no artificial ground cover. Animals were gathered in family groups to facilitate adaptation and further translocation.

Water was provided ad libitum, which was supplied by the Sapucaí-Mirim River. In addition, animals were fed with vegetables, greens and fruits twice daily. Food was cleaned with 10\% sodium hypochlorite solution for 30 minutes, followed by rinsing in water for ten minutes to minimize contamination.

\section{Case study}

Five A. caraya, two males (adult and juvenile) and three females (two adults, $\mathrm{A}$ and $\mathrm{B}$, and one subadult), died between August and October 2009. The period in captivity was 94 days for the young male and 142 for the adult male. For females, this period was 97 and 112 days for adults and 144 days for the sub-adult female.

The clinical history was similar for the five individuals despite some minor differences in the state and length of clinical signs. The animals began to show apathy, appetite loss, severe dehydration, hypothermia, hypoglycemia, apparent weight of loss, abdominal distension with gases on palpation. Feces showed a liquid aspect, brownish, melena and foul odor. Infective forms of protozoa were detected (cysts) on parasitological examinations. Treatment included antiparasitic, Nitazoxanide (Annita $0.375 \mathrm{~mL} / \mathrm{kg}$, FQM, Rio de Janeiro, RJ, Brazil); antibiotic, Ceftiofur (Excenel ${ }^{\circ}$ RTU $0.6 \mathrm{~mL}$, IV, Zoetis, São Paulo, SP, Brazil); intravenous fluid, Ringer solution with sodium lactate $(15 \mathrm{mg} / \mathrm{kg}$, SC, Baxter Hospital, São Paulo, SP, Brazil); hyperglycemic medication, monohydrate glucose $5 \mathrm{~g}$ (glycol-saline solution, 15 mg/kg, IV, Baxter Hospital , São Paulo, SP, Brazil); Vitamin B12 (Catosal ${ }^{\oplus}$, 1.0m L, IM, Bayer, São Paulo, SP, Brazil) and warming.

Sick individuals were also isolated. However, the animals' response was not satisfactory, evolving into severe prostration, anorexia and evident weakness. After an average of 118 days, the five animals died.

After death, the other individuals of their group were allocated to research centers and zoos, which allowed reallocating the population. Thus, new cages were assembled and fallowing was performed in cages for a period of at least seven days. This was carried out through disinfection (detergent and water) and sterilization (fire broom) of bars for the arrival of new individuals. Each cage received its own set of drinking and feeding bowls.

\section{Diagnostic procedures}

While animals exhibited clinical signs, parasitological tests were performed using the pool of cages. Direct parasitological tests by flotation methods were performed at the Laboratory of Parasitic Diseases of the School of Veterinary Medicine and Animal Science - University of São Paulo (FMVZ/USP), Brazil, with individual samples and group (cages). The techniques used were centrifugal-flotation in supersaturated sucrose solution $(\mathrm{d}=1.205 \mathrm{~g} / \mathrm{cm} 3)$ and the Willis technique, and sedimentation in waterether solution (1:1) (FAYER; XIAO, 2008; SANTOS, 2014). Additionally, fecal samples positive for Giardia spp. underwent polymerase chain reaction (PCR) with the nested PCR technique for the glutamate dehydrogenase gene $(\mathrm{GDH})$ at the Laboratory of Molecular Biology and Serology, FMVZ/USP (XIAO; FAYER, 2008). In addition, necropsy, histopathology and microbiology were performed in the five dead individuals in order to determine cause of death. During necropsy, fragments of all organs were collected, fixed in $10 \%$ buffered formalin ( $\mathrm{pH} 7.4$ ), and processed through the inclusion technique in paraffin wax, sectioned at $5 \mu \mathrm{m}$ and stained with hematoxylin \& eosin (H\&E) for histopathological evaluation at the 
Laboratory of Wildlife Comparative Pathology (LAPCOM), FMVZ/USP.

Bacteriological-culture and mycological-culture of liver, lung, spleen, small and large intestines and blood of dead animals were performed at the Laboratory of Infectious Diseases, FMVZ/USP.

\section{Results}

Coprological: Feces from the cages showed the presence of Giardia spp., Entamoeba spp. and Chilomastix spp. protozoan cysts. Among the dead animals, the presence of E. histolytica/dispar and $E$. coli, solely on the sub-adult female, was confirmed. Enzymatic profile or antigenic or genetic tests were not made in order to determine differences between $E$. histolytica (dysenteriae) (pathological specie) and E. dispar (not pathological species), thereby the term $E$. histolytica/dispar was adopted.

Necropsy: In the five animals, the necropsy findings were similar, especially in the intestinal tract, where severe coalescing necrotic enteritis was diagnosed with greater severity in colon and cecum (Figure 1).

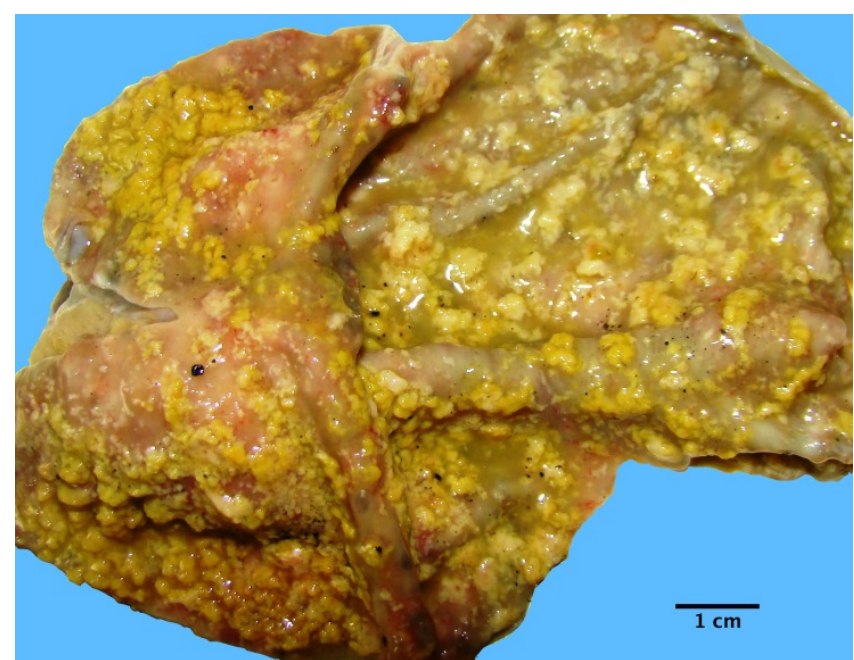

Figure 1 - Photography of cecum (juvenile male). Note severe necrosis and with mucosa detachment

Histopathology: In all dead animals, histopathological exams revealed the presence of structures morphologically similar to trophozoites of E. histolytica/dispar, alone or in small multifocal distribution groups in the mucosa, submucosa and lamina propria (Figure 2). In addition, secondary lesions were reported in lungs, liver and kidneys, associated with the chronicity of the infection.

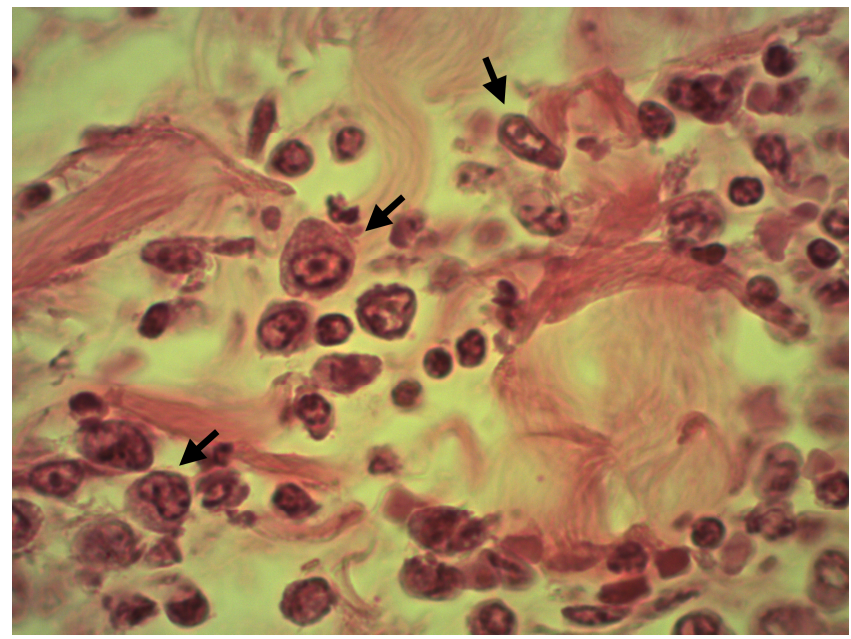

Figure 2 - Photomicrograph of large intestine (adult female). Observe the necrosis and mixed inflammatory cell exudation in lamina propria associated with structures morphologically similar to trophozoites of Entamoeba histolytica/dispar (arrows) (H\&E 100X)

Microbiology: The results of blood culture reported the growth of Escherichia coli was present in the adult females. The culture of samples of small and large intestines showed the presence of Escherichia coli, Enterococcus faecalis and Bacillus spp. in adult female A. Cultures of liver, lung and spleen fragments showed no bacterial growth in any of the individuals. Those results were compatible with histopathological evaluation; no bacterial cluster was detected in tissues collected for microbiology.

Molecular: In coproparasitological examination, and subsequently, in the molecular diagnostics by nested PCR technique, only the sub-adult female was positive for G. duodenalis. In Table 1, the relevant results of each diagnostic technique can be observed in detail. 
Table 1 - Diagnostic method and relevant results related to parasitosis that resulted in death of Alouatta caraya - São Paulo - 2009

\begin{tabular}{|c|c|}
\hline DIAGNOSTIC METHOD & RESULTS \\
\hline Parasitological: & $\begin{array}{l}\text { - Pools of feces from the cage tested by centrifugal flotation and direct stool examination: Cysts from Giardia spp. and } \\
\text { Entamoeba spp. } \\
\text { - Pools of feces from the second enclosure (Included dead animals): } \\
\circ \text { Amoebic cysts (rare); } \\
\circ \quad \text { Low quantity of Chilomastix spp. (+), } \\
\circ \text { Moderate quantity of Giardia spp. (++) cysts. } \\
\text { - For dead animals, only sub-adult female presented: } \\
\circ \text { E. histolytica/dispar (rare) } \\
\circ \quad \text { Moderate quantity of E. coli (++). }\end{array}$ \\
\hline Necropsy: & $\begin{array}{l}\text { - Small intestine: Greenish-brown or gooey white liquid. Mucosa: thickened and swollen with multifocal loss. } \\
\text { - Large intestine: Whitish and friable plates ( } 75 \% \text { of whole mucosa). The remaining } 25 \% \text { of mucosa was thickened, swollen and } \\
\text { congested. High quantity of greenish to brownish and gooey liquid with putrid odor. Cecum and colon with erosive appearance } \\
\text { and widespread detachment of mucosa (Tiflocolitis). } \\
\text { - Mesenteric lymph nodes: lymphadenomegaly. Black color, outside and inside (when cut). }\end{array}$ \\
\hline Histopathology: & $\begin{array}{l}\text { - Severe multifocal necrotic enteritis } \\
\text { - Lamina propria: Structures morphologically similar to } E \text {. histolytica/dispar, isolated, forming cavities in the tissue or in small } \\
\text { multifocal distribution groups. } \\
\text { - Sub-mucosa: Multifocal and moderate lymphoplasmacytic cell infiltration. } \\
\text { - Amoeboid parasitic forms: Different stages and sizes, spherical, irregular. Trophozoite, spongy and vacuous cytoplasm and a } \\
\text { - } \text { single nucleus, approximate size of } 15-20 \mu \mathrm{m} \text {. These structures were also observed in blood vessels } \\
\text { - } \quad \text { Adrenal glands: Adrenalitis with thrombosis, suggesting disseminated intra vascular coagulopathy. } \\
\text { - } \quad \text { Lungs: Chronic interstitial pneumonia. } \\
\text { - } \quad \text { Liver: Chronic hepatitis with confluent necrosis. } \\
\text { - } \text { Kidneys: Chronic interstitial glomerulonephritis. }\end{array}$ \\
\hline Microbiology: & $\begin{array}{l}\text { - } \quad \text { Blood Culture: Escherichia coli in both adult females. } \\
\text { - } \quad \text { Small and large intestines: Escherichia coli, Enterococcus faecalis and Bacillus spp. in adult female A. }\end{array}$ \\
\hline Molecular: & - Sub-adult female positive to Giardia duodenalis in parasitological tests: positive in molecular diagnosis (Nested PCR). \\
\hline
\end{tabular}




\section{Discussion}

\section{Outbreak's Modular Cofactors}

Stress is an adaptive response to a stressful event. However, during chronic stress, there is a permanent activation of the hypothalamic-pituitary-adrenal and sympathetic adreno medullary systems, resulting in constant physiological dysregulation, brain changes, accelerated aging, illness or death (MCEWEN, 2007). Teixeira et al. (2007) considered that in translocation and reintroduction programs, the conditions: environmental disturbance, captivity, transport, release, adaptation to the new environment and monitoring are sources of chronic stress. Furthermore, in the present case, the quarantine period was longer than 60 days due to waiting for permission for translocation from the environmental agencies. The group evaluated in this study experienced all these factors, and we believe they could promote immunosuppression in all of the five individuals, a decisive event before the high parasite load and subsequent clinical manifestation of the disease and death.

The group of non-human primates experienced loss and fragmentation of their habitat during these events; its members were captured and kept in captivity. At this stage, they were associated with other conditions, such as environmental contamination by urban sewage and management.

Balantidiasis (Balantidium coli), giardiaisis, and amoebic dysentery, caused by E. histolytica are among zoonotic waterborne infections. Both are transmitted by fecal contamination of water or food with cysts, which are discharged in feces. These diseases emerge from the lack of rigorous quality control of water and effluent (SCHUSTER; VISVESVARA, 2004) and inadequate infrastructure receiving fecal waste from humans (GRACZYK et al., 2002). It is known that urban effluents are not often treated before being discharged directly into rivers, as occurred in the city of São Joaquim before the dam was built and quarantine was located. Consequently, sanitary control was difficult, favoring continuous reinfections.
The management of a captive population can be a factor that promotes the maintenance of parasites in the group and transmission among individuals, so the development of a primate management program should consider age, reproductive status, diet, temperature, humidity of cages, and animal population density (MONTENEGRO et al., 2010).

In an attempt to keep social ties, WSC cages had a high population density, with different age levels and reproductive status, which can cause stress due to behavioral changes, such as an increase in aggressiveness, which has been described in marmosets (CAPEROS et al., 2011). It is suggested in other primates (Cebus capucinos) as a way to reduce this aggressive behavior to decrease contact with individuals in areas with high population densities (VAN WOLKENTEN et al., 2006).

Data on the natural history of species should be considered while preparing cages. In nature, Alouatta primates have very broad areas of use, either by individual or by group (GÓMEZ-POSADA et al., 2007; GAVAZZI et al., 2008; DUQUE; GÓMEZPOSADA, 2009), but cages failed to meet all the specific requirements for the species, and it may have increased the likelihood of contact of animal feces with feeders or drinkers, which possibly contributed to reinfection. However, as individuals were relocated due to the outbreak, and after allocation to zoos, this population factor may not have the same relevance any longer. Thus, immediate allocation is recommended so that the population load in WSC is not high and appropriate sanitation management is facilitated.

\section{Diagnosis}

Different authors have reported a very diverse prevalence of intestinal parasites in non-human primates regarding different species of helminthes and protozoa (ECKERT et al., 2006; VITAZKOVA; WADE, 2006; BRANDÃO et al., 2009). However, their presence is not associated with death in the wild. In this study, the presence of E. histolytica/dispar was 
associated with mortality in wild A. caraya, which were temporarily kept in cages.

The histopathological findings, together with clinical history and the results of fecal examinations, revealed that deaths were due to severe chronic necrotizing enterocolitis caused by protozoa, especially Entamoeba spp. In this study, clinical signs and histopathological lesions were consistent with those presented by Rhesus monkeys with chronic enterocolitis caused by protozoa (SESTAK et al., 2003) and $A$. caraya diagnosed with entamoebiasis caused by E. histolytica (MONTENEGRO et al., 2010). In these studies, the presence of severe hematochezia, loss of appetite, apathy, pale mucous membranes, chronic diarrhea and affectation are described, especially in colon, cecum and terminal ileum. Mononuclear infiltrates were also found in mucosa, submucosa, lamina propria, blood vessels, as well as presence of aggregates and isolated forms of these amoeboid stages in these regions.

Micro-abscesses in liver, brain and lungs are also described. After penetrating the intestine, E. histolytica may be carried by the bloodstream to other organs, causing micro-abscesses (SCHUSTER; VISVESVARA, 2004; MONTENEGRO et al., 2010), although such lesions were not observed in these organs on histopathological evaluation.

In contrast, other studies have corroborated the great diversity of species of protozoa affecting primates in captivity (GÓMEZ et al., 1996; LEVECKE et al., 2007; MARTÍNEZ-DÍAZ et al., 2011). In Brazil, in breeding Cebusapella, Macaca mulatta, Callithrix jacchus and Callithrix penicillata in captivity, the presence of Cryptosporidium, Giardia, Cystoisospora and Balantidium has been reported (SILVA et al., 2008). Fecal examinations in A. caraya evaluated in this study also revealed the presence of intestinal flagellate protozoa Chilomastix and Giardia. These and others, such as Retortamonas and Trichomonas, can be parasitic or commensal microorganisms in humans, and may also affect Alouatta spp. (STUART et al., 1998).
In Belize, asymptomatic Alouatta pigra individuals were identified with $G$. duodenalis, with the genotypes $A$ and $B$ transmissible from man to non-human primates (VITAZKOVA; WADE, 2006). In Brazil, $G$. duodenalis, genotype $\mathrm{A}$, has been reported in asymptomatic Alouatta clamitans and A. caraya individuals kept in captivity (VOLOTÃO et al., 2008; SANTOS et al., 2011).

The other protozoa detected in this study, for example, Chilomastix spp., was considered as commensal or opportunistic protozoa (SESTAK et al., 2003), and its presence was not necessarily involved with the clinical condition observed in the animals.

\section{Prophylaxis}

Despite conventional prophylactic treatments, several factors are associated with the difficulty of controlling protozoa in non-human primates kept in captivity, among them, the direct cycle of the parasite, the situations favored by captivity, life habits, institution infrastructure and challenges posed by human resources (GÓMEZ et al., 1996). All these factors may be involved in disease outbreaks because even though they had an adequate and supportive treatment (KINDLOVITS; KINDLOVITS, 2009; KRAMER et al., 2009), this procedure was not enough to avoid the death of the five animals. However, the wildlife management program adopted effective prophylactic measures, which rapidly decreased the number of sick animals and prevented new deaths.

\section{Interspecies transmission implications}

People susceptible to infection by E. histolytica and E. coli are those who work with monkeys, slaughter animals for food or are pet monkey owners (SCHUSTER; VISVESVARA, 2004). The presence of protozoa could be related to interspecies transmission between WSC staff and howler monkeys, which was reduced with appropriate management practices. Furthermore, it is possible that the displacement of primate populations increased the contact with 
human populations, favoring protozoa and other microorganism transmission.

This study showed that Entamoeba spp., Giardia spp. and Chilomastix spp. are intestinal protozoa found in non-human primates captured from wildlife, which may lead to death due to stressful conditions inherent to captivity. Multiple diagnostic techniques can be used to detect protozoa, including histopathological, molecular and serological ones (LANGHOUT et al., 2010). On the other hand, as performed in this study, the implementation of basic laboratory techniques (parasitology) in WSC enables the epidemiological surveillance of captive populations, establishment of an accurate and prompt diagnosis, the provision of effective preventive measures and settlement $t$ of adequate treatments.

\section{References}

AMATO, J. F. R.; AMATO, S. B.; CALEGARO-MARQUES, C.; BICCA-MARQUES, J. C. Trypanoxyuris (trypanoxyuris) minutus associated with the death of a wild southern brown Howler Monkey, Alouatta guariba clamitans, in Rio Grande do Sul, Brazil. Arquivos do Instituto Biológico, v. 69, n. 4, p. 99-102, 2002.

BRANDÃO, M. L.; CHAME, M.; CORDEIRO, J. L. P.; CHAVES, S. A. D. M. Diversidade de helmintos intestinais em mamíferos silvestres e domésticos na Caatinga do Parque Nacional Serra da Capivara, Sudeste do Piauí, Brasil. Revista Brasileira de Parasitologia Veterinária, v. 18, p. 19-28, 2009. Suplemment 1. doi: 10.4322/rbpv.018e1004.

CAPEROS, J. M.; SÁNCHEZ, S.; PELÁEZ, F.; FIDALGO, A.; MORCILLO, A. The effect of crowding on the social behavior of the cooperatively breeding cotton-top tamarins (Saguinus oedipus). International Journal of Primatology, v. 32, n. 5, p. 1179-1189, 2011. doi: 10.1007/s10764-011-9534-7.

CRISTÓBAL-AZKARATE, J.; HERVIER, B.; VEGASCARRILLO, S.; OSORIO-SARABIA, D.; RODRÍGUEZLUNA, E.; VEÀ, J. J. Parasitic infections of three Mexican howler monkey groups (Alouatta palliata mexicana) living in forest fragments in Mexico. Primates, v. 51, n. 3, p. 231-239, 2010. doi: 10.1007/s10329-010-0193-7.
Capture and management programs of groups of neotropical non-human primates should offer favorable maintenance conditions to reduce subsequent stress, taking into consideration the ecology and natural history of each species.

\section{Acknowledgements}

To PEC-PG/CAPES for the scholarship granted. To the Central Elétrica Anhanguera S.A. and the Wildlife Management Consultoria Veterinária Ltda. for logistic and financial support. To the laboratories of Parasitic Diseases, Infectious Diseases, Applied Molecular Biology and Serology and Comparative Pathology of Wild Animals at FMVZ/USP, Brazil, for carrying out diagnostic tests.

DUQUE, N. R.; GÓMEZ-POSADA, C. Sympatric Alouatta seniculus and Cebus capucinus in an Andean forest fragment in Colombia: a survey of population density. Neotropical Primates, v. 16, n. 2, p. 51-56, 2009. doi: 10.1896/044.016.0201.

ECKERT, K. A.; HAHN, N. E.; GENZ, A.; KITCHEN, D. M.; STUART, M. D.; AVERBECK, G. A.; STROMBERG, B. E.; MARKOWITZ, H. Coprological surveys of Alouatta pigra at two sites in Belize. International Journal of Primatology, v. 27, n. 1, p. 227-238, 2006. doi: 10.1007/s10764-005-9010-3.

FAYER, R; XIAO, L. Cryptosporidium and cryptosporidiosis. Boca Raton: IWA Publishing, CRC Press, 2008. 576 p.

GAVAZZI, A. J.; CORNICK, L. A.; MARKOWITZ, T. M.; GREEN, D.; MARKOWITZ, H. Density, distribution, and home range of the black howler monkey (Alouatta pigra) at Lamanai, Belize. Journal of Mammalogy, v. 89, n. 5, p. 11051112, 2008. doi: 10.1644/07-mamm-a-063.1.

GÓMEZ, M. S.; GRACENEA, M.; MONTOLIU, I.; FELIU, C.; MONLEON, A.; FERNANDEZ, J.; ENSEÑAT, C. Intestinal parasitism - protozoa and helminths - in primates at the Barcelona Zoo. Journal of Medical Primatology, v. 25, n. 6, p. 419-423, 1996. doi: 10.1111/j.1600-0684.1996.tb00038.x. 
GÓMEZ-POSADA， C.; MARTÍNEZ，J.; GIRALDO, P.; KATTAN, G. H. Density, habitat use, and ranging patterns of red howler monkeys in a Colombian Andean Forest. Neotropical Primates, v. 14, n. 1, p. 2-10, 2007. doi: 10.1896/044.014.0102.

GRACZYK, T. K.; BOSCO-NIZEYI, J.; SSEBIDE, B.; THOMPSON, R. C. A.; READ, C.; CRANFIELD, M. R. Anthropozoonotic Giardia duodenalis genotype (assemblage) a infections in habitats of free-ranging human-habituated gorillas, Uganda. Journal of Parasitology, v. 88, n. 5, p. 905909, 2002. doi: 10.2307/3285529.

KIERULFF, M. C. M.; CARVALHO, M. P. Alouatta caraya (Humboldt, 1812) Primates, Atelidae. In: BRESSAN, P. M.; KIERULFF, M. C. M.; SUGIEDA, A. M. (Ed.). Fauna ameaçada de extinção no estado de São Paulo: vertebrados. São Paulo: Fundação Parque Zoológico de São Paulo; Secretaria do Meio Ambiente, 2009. p. 645.

KINDLOVITS, A.; KINDLOVITS, L. M. Posologia de medicamentos utilizados em primatas não-humanos. In: KINDLOVITS, A.; KINDLOVITS, L. M. (Ed.). Clínica e terapêutica em primatas neotropicais. 2. ed. Rio de Janeiro: L.F. Livros de Veterinária, 2009. cap. 33, p. 425-436.

KRAMER, J. A.; HACHEY, A. M.; WACHTMAN, L. M.; MANSFIELD, K. G. Treatment of giardiasis in common marmosets (Callithrix jacchus) with tinidazole. Comparative Medicine, v. 59, n. 2, p. 174-179, 2009.

LANGHOUT, M. van Z.; REED, P.; FOX, M. Validation of multiple diagnostic techniques to detect Cryptosporidium sp. and Giardia sp. in free-ranging western lowland gorillas (Gorilla gorilla gorilla) and observations on the prevalence of these protozoan infections in two populations in Gabon. Journal of Zoo and Wildlife Medicine, v. 41, n. 2, p. 210217, 2010. doi: 10.1638/2009-0051R1.1.

LEVECKE, B.; DORNY, P.; GEURDEN, T.; VERCAMMEN, F.; VERCRUYSSE, J. Gastrointestinal protozoa in non-human primates of four zoological gardens in Belgium. Veterinary Parasitology, v. 148, n. 3-4, p. 236-246, 2007. doi: 10.1016/j.vetpar.2007.06.020.

MARTÍNEZ-DÍAZ, R. A.; SANSANO-MAESTRE, J.; MARTÍNEZ-HERRERO, M. D. C.; PONCE-GORDO, F.; GÓMEZ-MUÑOZ, M. T. Occurrence and genetic characterization of Giardia duodenalis from captive nonhuman primates by multi-locus sequence analysis. Parasitology Research, v. 109, n. 3, p. 539-544, 2011. doi: 10.1007/s00436-011-2281-z.
MCEWEN, B. S. Physiology and neurobiology of stress and adaptation: central role of the brain. Physiological Reviews, v. 87, n. 3, p. 873-904, 2007. doi: 10.1152/physrev.00041.2006.

MOBERG, G. P. Biological response to stress: Implications for animal welfare. In: MOBERG, G. P.; MENCH, J. A. (Ed.). The biology of animal stress: basic principles and implications for animal walfare. Wallingford: CAB International, 2000. cap. 1, p. 1-21.

MONTENEGRO, M.; SÁNCHEZ NEGRETTE, M.; LÉRTORA, W. J. Diagnóstico histopatológico de entamoebiosis en un primate en cautiverio (Alouatta caraya). Revista Veterinária, v. 21, n. 1, p. 59-62, 2010.

SÁNCHEZ-SARMIENTO, A. $\quad$ M.; ZWARG, T.; FERNANDES-SANTOS, R. C.; GUIMARÃES-LUIZ, T.; GENOY-PUERTO, A.; MATUSHIMA, E. R. Hematological parameters and the variations resulting from stress of Alouatta caraya during a wildlife rescue program in Brazil. American Journal of Primatology, v. 77, n. 3, p. 246-253, 2015. doi: 10.1002/ajp.22327.

SANTOS, R. C. F. Criptosporidiose, Giardiose e Amebiose. In: CUBAS, Z. S.; SILVA, J. C. R.; CATÃO-DIAS, J. L. (Ed.) Tratado de animais selvagens. 2. ed. São Paulo: Roca, 2014. v. 2, p. 1453-1480.

SANTOS, R. C. F.; SOARES, R. M.; CUBAS, Z. S.; MORAES, W.; SANTOS, L. C.; SOUZA, S. L. P.; PRIOSTE, F.; MATUSHIMA, E. R. Occurrence and molecular characterization of Giardia duodenalis from captive wild animals. In: ANNUAL INTERNATIONAL CONFERENCE OF THE WILDLIFE DISEASE ASSOCIATION, 60., 2011, Quebéc. Anais... Quebéc: Wildlife Disease Association, 2011. p. 150.

SCHUSTER, F. L.; VISVESVARA, G. S. Amebae and ciliated protozoa as causal agents of waterborne zoonotic disease. Veterinary Parasitology, v. 126, n. 1-2, p. 91-120, 2004. doi: 10.1016/j.vetpar.2004.09.019.

SESTAK, K.; MERRITT, C. K.; BORDA, J.; SAYLOR, E.; SCHWAMBERGER, S. R.; COGSWELL, F.; DIDIER, E. S.; DIDIER, P. J.; PLAUCHE, G.; BOHM, R. P.; AYE, P. P.; ALEXA, P.; WARD, R. L.; LACKNER, A. A. Infectious agent and immune response characteristics of chronic enterocolitis in captive rhesus macaques. Infection and Immunity, v. 71, n. 7, p. 4079-4086, 2003. doi: 10.1128/IAI.71.7.4079-4086.2003.

SILVA, A. S.; CORADINI, G. P.; GRESSLER, L. T.; SOARES, J. F.; LARA, V. M.; CARREGARO, A. B.; MONTEIRO, S. G. Occurrence of gastrointestinal protozoa 
in primates kept in captivity in the Southern region of Brazil. Ciência Rural, v. 38, n. 9, p. 2658-2661, 2008. doi: 10.1590/S0103-84782008000900044.

STUART, M.; PENDERGAST, V.; RUMFELT, S.; PIERBERG, S.; GREENSPAN, L.; GLANDER, K.; CLARKE, M. Parasites of wild howlers (Alouatta spp.). International Journal of Primatology, v. 19, n. 3, p. 493512, 1998. doi: 10.1023/A:1020312506375.

TEIXEIRA, C. P.; AZEVEDO, C. S.; MENDL, M.; CIPRESTE, C. F.; YOUNG, R. J. Revisiting translocation and reintroduction programmes: the importance of considering stress. Animal Behaviour, v. 73, n. 1, p. 1-13, 2007. doi: 10.1016/j.anbehav.2006.06.002.

THOMPSON, R. C. A.; SMITH, A. Zoonotic enteric protozoa. Veterinary Parasitology, v. 182, n. 1, p. 70-78, 2011. doi: 10.1016/j.vetpar.2011.07.016.

THOMPSON, S. C. Giardia lamblia in children and the child care setting: A review of the literature. Journal of Paediatrics and Child Health, v. 30, n. 3, p. 202-209, 1994. doi: 10.1111/j.1440-1754.1994.tb00620.x.

ULRICH, R.; BÖER, M.; HERDER, V.; SPITZBARTH, I.; HEWICKER-TRAUTWEIN, M.; BAUMGÄRTNER, W.;
WOHLSEIN, P. Epizootic fatal amebiasis in an outdoor group of Old World monkeys. Journal of Medical Primatology, v. 39, n. 3, p. 160-165, 2010. doi: 10.1111/j.1600-0684.2010.00405.x.

VAN WOLKENTEN, M. L.; DAVIS, J. M.; GONG, M. L.; WAAL, F. B. M. Coping with acute crowding by Cebus apella. International Journal of Primatology, v. 27, n. 5, p. 12411256, 2006. doi: 10.1007/s10764-006-9070-z.

VITAZKOVA, S. K.; WADE, S. E. Parasites of free-ranging black howler monkeys (Alouatta pigra) from Belize and Mexico. American Journal of Primatology, v. 68, n. 11, p. 1089-1097, 2006. doi: 10.1002/ajp.20309.

VOLOTÃO, A. C. C.; SOUZA JÚNIOR, J. C.; GRASSINI, C.; PERALTA, J. M.; FERNANDES, O. Genotyping of Giardia duodenalis from Southern Brown Howler Monkeys (Alouatta clamitans) from Brazil. Veterinary Parasitology, v. 158, n. 12, p. 133-137, 2008. doi: 10.1016/j.vetpar.2008.07.003.

XIAO, L.; FAYER, R. Molecular characterisation of species and genotypes of Cryptosporidium and Giardia and assessment of zoonotic transmission. International Journal for Parasitology, v. 38, n. 11, p. 1239-1255, 2008. doi: 10.1016/j.ijpara.2008.03.006. 